\title{
NOTES AND QUERIES
}

\section{THE MEANING OF THE TITLE "CHELEBI"}

A valuable article in the Encyclopoedia of Islam (ib., p. 831) discusses the origin of this Turkish title, but its derivation is not settled. It was first borne, as far as is known, by Chelebi Husām-ud-Dīn, successor of Jaläl-ud-Dīn Rūmī, in the thirteenth century (ib., p. 832). It was also borne by all the sons of Bayyazid I, but according to Gibbons (The Foundation of the Ottoman Empire, p. 195), the eldest son of Bāyazìd was Sulaimān Chelebi, while his second son, or the son whom he esteemed second only to Sulaimān, was nicknamed Kiri-Chelebi (Girijilibi in Rabbi Joseph : Chronicles, ib., p. 257). What authority is there for styling Kiri-Chelebi a nickname? Kiri- appears to mean " after-" or "next-" Chelebi, so that the term might mean " next heir-apparent", like the Sanskrit dwistānia-if Chelebi meant " heirapparent".

It is suggested that Chelebi is derived from the Arabic șalb or șulb, "loins," and that it originally denoted "true-born" or "lawful heir", and so "next heir" -in the case of sovereignty. In religious succession it may have denoted "physical successor" as opposed to "spiritual successor" (khalīfa). Among the Baqtäsh there appear to be two lines of succession to the headship of the Order, one by spiritual descent, the other by natural descent; so that there are two heads, each with his own following. In Persian farzand salabi appears as meaning "own" or "actual" son, e.g. in the Rashahät-i'Ain-ul-Hayāt (maqsad i). The question is: Is the Maulawì Chelebi invariably a physical son of the founder's kin or is the title applied also to one who succeeds to its headship by spiritual adoption pure and simple?

H. A. R.

\section{PRESTER JOHN AND BENIN.}

Iv Barros' Da Asia, dec. i, book iii, p. 177, we find that in 1486 " the King of Benij [= Benin, more properly Bini], whose kingdom lies between the kingdom of Congo and the Castle of S. Jorge da Mina" 
[= Elmina], sent an embassy to Dom João II of Portugal, asking for Christian preachers to be sent to his people. Consequently a mission was sent out and a factory established at Gato (Egwaton), a place still in existence on the Ovia river. One reason for the very prompt response to the Benin chief's message was the hope of opening up communications with Prester John (then believed to be located in Abyssinia), suggested by the following information obtained from the envoy (ib., p. 181): "To the east of the King of Benij, at a distance of twenty months' journey, which . . . might be 250 of our leagues, there was a King the most powerful of all in those parts, whom they called OGANE, who among the pagan princes of the districts (comarcas) of Benij, was held in as great veneration as among us the highest prelates. To whom by a most ancient custom, the Kings of Benin, on succeeding to the crown, used to send their ambassadors with a large present, notifying him that, through the death of such an one (Foão) they had succeeded to the said Kingdom of Benij, in the which they besought him to confirm them. As a token of which confirmation this Prince Ogané sent them a staff and a covering for the head after the fashion of the Spanish helmets (capacetes), all of shining brass, instead of a sceptre and crown, and he also sent them a cross of the same brass to wear round the neck, of the same shape as those worn by the Commanders of the Order of St. John." The historian adds that these messengers were never allowed to see the Ogané, who sat behind curtains, and, when the messenger was taking his leave, stretched out one foot, to which he might do homage.

As it seems in every way unlikely that a fifteenth century Bini (Yoruba) chief should have received his investiture from Abyssinia, one is tempted to think the "twenty months' journey" is either a misunderstanding of a statement transmitted through (probably) very imperfect interpreters, or a conjecture of the Portuguese inquirers, who, having the idea of Prester John rooted in their minds, could not conceive of him as only twenty days distant from the King of Benin. The late Mr. Dennett, whom I consulted on the subject, told me that all the sixteen chiefs of the Yoruba confederacy (of whom the OвA Ado of Benin is one, along with the Alafin of Oyo, the Alake of Abeokuta, etc.) received their investiture from the $\mathrm{ONI}_{\mathrm{NI}}$ of IFE-Ife being the ancient tribal centre and sanctuary. All the sixteen chiefs are held to be descended from the sons of the first Oni. Mr. Dennett thought OGane a contraction of OGA, "chief," and INE "one of the four pairs of chiefs said to have come from IFE with the son of the 
Oni called Eweka, the first Yoruba King of the Eras (now called the BINI)".

It is thus evident that Barros" "Ogané" is the Oni of Ife. Ogané might have been the title (or one of the titles) of the King of Benin himself, or one of his sub-chiefs; and, whether the communications passed entirely through interpreters, or the envoy spoke Portuguese of sorts, the mistake is not very surprising. The "crowns" of the Yoruba chiefs at the present day are caps adorned with gold or brass plates, sometimes exhibiting symbolical figures (e.g. the chameleon of Abeokuta); and a staff or sceptre also belongs to their insignia. The cross-shaped pendant I have so far been unable to trace, but the figure of the cross occurs in native symbolism-cf. the illustrations on pp. 215, 225 of Mr. Dennett's book, At the Back of the Black Man's Mind (Macmillan, 1906).

\section{A. Werner.}

\section{LEIBNIZ AND FU-HSI}

TeE ordinary numbers with which we are acquainted in arithmetic are expressed by means of multiples of powers of 10 : for instance, $4705=4 \times 10^{3}+7 \times 10^{2}+0 \times 10+5$.

This method of representing numbers is called the denary scale of notation, and 10 is said to be the base of the scale. In like manner any other number than 10 may be taken as the base of a scale of notation. If 2 is the base, "two" will be written 10 , "three" will be written 11, "four" (i.e. $2^{2}$ ) will be written 100 , and so on.

The mathematician Leibniz (1646-1716), who wrote several essays on the binary scale of notation, saw in it a symbol of "One God and Nothing else beside", and recommended it on this ground to his patron the Duke of Brunswick-Wolfenbüttel. Through the Catholic missionary Père Bouvet (one of the six "mathématiciens du Roi" sent by Louis to the court of Peking) Leibniz became acquainted with the diagrams of Fu Hsi 伏羲 (c. 3000 B.c.), and recognized the fact that the Pa Kuei 八卦, or “Eight Diagrams”, were merely the numbers 7 to 0 , written in a binary notation. Similarly, that the Sixty-four Diagrams were the numbers 63 to 0 written in the same notation.

The Eight Diagrams, written in Fu Hsi's order, are 三, 三, 三,

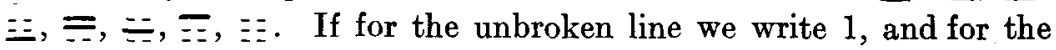
broken line 0 , we $\operatorname{get}^{1} 111,110,101,100,011,010,001$, and 000 .

1 The diagrams are to be read from the bottom upwards, as in the Book of Changes. 